\title{
Successful pregnancy in a patient with Ebstein's anomaly
}

\author{
W. A. Littler \\ From Liverpool Regional Cardiac Centre, Sefton General Hospital, Smithdown Road, \\ Liverpool 15
}

A case is described of a successful pregnancy in a woman with Ebstein's anomaly. It is suggested that careful assessment should be made before advising against starting or terminating pregnancies, since successful outcomes are possible.

The incidence of Ebstein's anomaly in the general population has been estimated as $I$ in 210,000, or less than I per cent of all congenital heart defects (Keith, Rowe, and Vlad, 1958), and it has an equal sex ratio.

Since the introduction of cardiac catheterization, intracardiac electrocardiography, and angiocardiography the diagnosis of this anomaly has confidently been made during life (Kerwin, 1955; Kistin, Evans, and Brigulio, 1955), and corrective operations are being carried out in some centres (Lillehei, Kalke, and Carlson, 1967). Successful pregnancy in a patient with Ebstein's anomaly is uncommon (Copeland et al., 1963).

\section{Case report}

This patient, a 23-year-old woman, had first been referred to this centre at the age of 13 years because of a cardiac murmur. Until that time she had been well and there was no history of rheumatic fever. Physical examination at that time showed a well-developed young girl, with no cyanosis or clubbing. On auscultation third and fourth heart sounds were present, while the first sound was split and diminished in intensity; there was wide fixed splitting of the second sound. A loud pansystolic murmur, associated with a thrill, was best heard in the third and fourth left intercostal spaces parasternally together with a superficial scratchy diastolic murmur. The heart rhythm was regular and the arterial pulses were normal. Jugular venous pressure was not raised and a blood pressure of $\mathrm{IIO} / 60 \mathrm{~mm}$. $\mathrm{Hg}$ was recorded. Other systems were clinically normal. An electrocardiogram showed complete right bundlebranch block with a prolonged PR interval (0.24 sec.); a large heart with a sharply outlined cardiac silhouette was seen in the chest radiograph.
Cardiac catheterization showed an atrial septal defect with a small left-to-right shunt and normal pressures in all four chambers. Intracardiac electrocardiography was not carried out. A diagnosis of Ebstein's anomaly was considered a more likely possibility than an atrial septal defect alone in view of the electrocardiographic and radiological findings.

In April I968, a ro-week pregnancy was terminated because of the diagnosis of Ebstein's anomaly, though she was symptom free at this time. Readmission to this Unit was occasioned by the patient's desire for a firm diagnosis to be made.

The clinical, electrocardiographic, and radiological features were essentially the same as those recorded to years previously. Right heart catheterization revealed that neither the left-to-right shunt nor the pressures had altered significantly. An intracardiac electrocardiogram showed right ventricular complexes where the pressure tracings showed an atrial pressure pulse. A considerable amount of tricuspid regurgitation was shown by right ventricular angiography; the tricuspid valve itself was displaced well to the left, and the cusps were abnormal.

The diagnosis of Ebstein's anomaly was thus confirmed and no treatment was advised.

Eight weeks later the patient developed a low grade pyrexia and a sudden right-sided hemiparesis associated with motor dysphasia. No rhythm change was noticed at this time. Streptococcus viridans was grown from one blood culture. A month's course of intravenous penicillin together with intramuscular streptomycin and oral warfarin sodium were given. Both her pyrexia and neurological signs settled quickly. One month afterwards she had two attacks of Jacksonian epilepsy on the right side of her body, which were controlled with phenobarbitone and epanutin.

When seen in March 1969 she was at least I2 
weeks pregnant and anxious to have the baby. The pregnancy was allowed to continue, but anticoagulants were stopped in view of the possible risks to the foetus.

Close supervision was maintained throughout the pregnancy and the last trimester was spent in hospital. The patient remained symptom free apart from some ankle oedema which quickly settled with rest in bed. No cardiac drugs were required. At 36 weeks she went into spontaneous labour and was delivered of a healthy female infant weighing $2267 \mathrm{~g}$. The patient remained symptomless throughout parturition. Procaine penicillin 300,000 units daily was given from the onset of labour for one month.

\section{Discussion}

Though the average life expectancy of a patient with Ebstein's anomaly is 25 to 30 years, there exists a wide spectrum of severity. Adams and Hudson (I956) reported survival to the age of 79 years in a woman. In reviewing 120 cases that had died, Gasul, Arcilla, and Lev (I966) found that 59 per cent were dead by 20 years of age, 79 per cent by 30 years, and 87 per cent by 40 years. In the combined series of Mayer, Nadas, and Ongley (I957), Vacca, Bussmann, and Mudd (1958), and Schiebler et al. (1959) there were 62 female patients with Ebstein's anomaly; half of these could be regarded as being, or having been, of child-bearing age but there was no mention of pregnancy in any of these women. Copeland et al. (1963) studied I03 women with congenital heart disease who had a total of 372 pregnancies; 3 of these women had Ebstein's anomaly with a total of 6 pregnancies; there are few details about these pregnancies other than the fact that 2 of the women were cyanotic and that 2 of the pregnancies ended in abortion.

The likeliest reasons for such women not having children are the severity of their symptoms, or medical advice against starting, or perhaps continuing, a pregnancy. Our patient had one pregnancy terminated because of her heart lesion even though she was symptomless at the time. There are several possible hazards during pregnancy in this condition. Cyanosis, if present, leads to a high incidence of spontaneous abortions (Wooley et al., I96I ; Copeland et al., 1963) or if born live, the offspring of a cyanotic mother tends to be smaller and less robust than a normal child. The presence of pulmonary hypertension also increases the risk of foetal death (Wooley et al., r96I).

Congestive heart failure and sudden collapse with no obvious cause are the commonest causes of death in Ebstein's anomaly. The increased circulating blood volume during pregnancy may precipitate heart failure, while severe exertion, and possibly anaesthesia, during labour may produce sudden death. The risk of death from paradoxical embolism is greater during pregnancy because of the higher incidence of thromboembolic disease. A relatively good prognosis in our case is indicated by the absence of cyanosis, cardiac failure, and arrhythmias either before or during pregnancy. While bacterial endocarditis is not particularly associated with Ebstein's anomaly, it seems likely that it was responsible for the cerebral embolus in this case. Embolic phenomena, without associated infection, followed cardiac catheterization in the case of Baker, Brinton, and Channell (1950). Their patient died 2I days after catheterization from gangrene of both legs, and at necropsy there was thrombus in both the left atrium and the left ventricle. Paradoxical cerebral embolism has been recorded as the cause of death in several cases (Vacca et al., 1958). Anticoagulants were given to our patient because of such possibilities.

This case report suggests that women with Ebstein's anomaly should be carefully assessed before advising them against starting or terminating a pregnancy, since a successful outcome may be achieved.

I wish to thank Dr. E. J. Epstein, who undertook the medical care of this patient, and Mr. P. Walker, who supervised her obstetrical management, for permission to publish details of this case.

\section{References}

Adams, J. C. L., and Hudson, R. (1956). A case of Ebstein's anomaly surviving to the age of 79 . British Heart Fournal, 18, 129.

Baker, C., Brinton, W. D., and Channell, G. D. (1950). Ebstein's disease. Guy's Hospital Reports, 99, 247.

Copeland, W. E., Wooley, C. F., Ryan, J. M., Runco, V., and Levin, H. S. (1963). Pregnancy and congenital heart disease. American fournal of Obstetrics and Gynecology, 86, 107.

Gasul, B. M., Arcilla, R. A., and Lev, M. (1966). Heart Disease in Children: Diagnosis and Treatment. J. B. Lippincott, Philadelphia.

Keith, J. D., Rowe, R. D., and Vlad, P. (1958). Heart Disease in Infancy and Childhood, p. 314. Macmillan, New York.

Kerwin, A. J. (1955). Ebstein's anomaly: Report of a case diagnosed during life. British Heart fournal, 17, 109.

Kistin, A. D., Evans, J. M., and Brigulio, A. E. (1955). Ebstein's anomaly of the tricuspid valve: Angiocardiographic diagnosis. American Heart fournal, 50, 634 .

Lillehei, C. W., Kalke, B. R., and Carlson, R. G. (I967). Evolution of corrective surgery for Ebstein's anomaly. Circulation, 35, Suppl. I, p. I I I.

Mayer, F. E., Nadas, A. S., and Ongley, P. A. (I957). Ebstein's anomaly: Presentation of 10 cases. Circulation, 16, 1057. 
Schiebler, G. L., Adams, P., Anderson, R. C., Amplatz, K., and Lester, R. G. (1959). Clinical studies of 23 cases of Ebstein's anomaly of the tricuspid valve. Circulation, 19, 165.

Vacca, J. B., Bussmann, D. W., and Mudd, J. G.
(1958). Ebstein's anomaly: Complete review of 108 cases. American fournal of Cardiology, 2, 210.

Wooley, C. F., Runco, V., Levin, H. S., and Ryan, J. M. (I96I). Pregnancy and congenital heart disease. Circulation, 24, 1075. 